\title{
Fetofetal transfusion syndrome: do the neonatal criteria apply in utero?
}

\author{
N M Fisk, A Borrell, C Hubinont, Y Tannirandorn, U Nicolini, C H Rodeck
}

\begin{abstract}
Thirteen fetuses (five twin, one triplet) were compromised by fetofetal transfusion syndrome in six pregnancies, five in the mid trimester, and one in the third trimester. This diagnosis, which was suspected because of ultrasound findings of discordant growth, discordant amniotic fluid volumes, concordant external genitalia, and monochorial placentation, was confirmed postnatally in each. Nine fetuses underwent blood sampling to aid diagnosis and assessment of fetal wellbeing. In contrast to fetofetal transfusion syndrome investigated postnatally, a difference in haemoglobin concentration of $50 \mathrm{~g} / 1$ or more in utero was found in only one pregnancy, which was near term, although all had fetal erythroblastaemia and a difference in weight of $20 \%$ or more. In vivo confirmation of shared circulation was achieved in two pregnancies by transfusing adult $R h$ negative red cells into the smaller fetus and then detecting them by Kleihauer testing in blood aspirated from the larger. Invasive procedures also yielded information on fetal blood gas measurements (acidaemia in four and hypoxaemia in six) and amniotic pressure (raised in two). We suggest that comparison of haemoglobin concentrations is inaccurate in fetofetal transfusion syndrome in utero, the diagnosis of which may necessitate detection of a shared circulation using a marker such as adult red cells.
\end{abstract}

Although vascular communications are found in the placentas of almost all monochorial twin pregnancies, clinical signs of twin to twin transfusion occur in only 4-26\%. ${ }^{2}$ The pathophysiology of this condition, known as fetofetal transfusion syndrome, is poorly understood. In general however, the donor twin becomes anaemic, growth is retarded, and it develops oligohydramnios, whereas the recipient develops hydrops, cardiomegaly, and polyhydramnios. ${ }^{3}$

Most reported cases have been diagnosed postnatally or at necropsy. The standard neonatal criteria comprise a difference in cord haemoglobin concentrations of $50 \mathrm{~g} / \mathrm{l}$ or more, and a difference in birth weights of $20 \%$ or more, ${ }^{4-6}$ although the latter criterion is not necessarily present in the acute form of fetofetal transfusion syndrome that occurs in labour. ${ }^{7}$ Certain antenatal ultrasound appearances are highly suggestive of fetofetal transfusion syndrome, ${ }^{8-11}$ principally discrepant growth, and amniotic fluid volumes between monochorionic diamnionic twins. ${ }^{81011}$ Discordant

ionic diamnionic twins. 10 in Discordant

growth, however, is a common complication of twin pregnancies, and causes other than fetofetal transfusion syndrome exist for discordant amniotic fluid volume. Signs of hydrops fetalis on ultrasound scan are occasionally found in the recipient, ${ }^{10}{ }^{11}$ rarely in the donor, ${ }^{4}$ and exceptionally in both. ${ }^{12}$ As all the above ultrasound features are non-specific, more accurate methods of antenatal diagnosis are needed if its associated high perinatal mortality rate of $40-81 \%$ is to be reduced. ${ }^{8-10} 13$

Pregnancies complicated by fetofetal transfusion syndrome will increasingly be evaluated in utero now that some of its signs-for example, intrauterine growth retardation, hydrops, and abnormal amniotic fluid volume, have become accepted indications for fetal blood sampling. Although precise criteria exist for the postnatal diagnosis of fetofetal transfusion syndrome, none have as yet been defined for its diagnosis in utero. We describe our experience of detailed fetal assessment in fetofetal transfusion syndrome using ultrasound scanning and fetal blood sampling.

Patients and methods

Among multiple pregnancies referred over a three year period for investigation of discordant fetal growth, the diagnosis of fetofetal transfusion syndrome was strongly suspected in six (five twin, one triplet) because of ultrasonographic findings of discrepant amniotic fluid volume, concordant external genitalia, and a monochorionic placenta, in addition to discordant intrauterine growth retardation. Gestational ages ranged from 17-36 weeks, with only one patient beyond 27 weeks.

Initial assessment comprised detailed ultrasound scanning, examining in particular the site of the placenta, the thickness of the septum, ${ }^{14}$ the depth of the amniotic fluid pools, and the presence of hydrops. In four cases, pulsed Doppler studies of umbilical arterial flow velocity waveforms were undertaken (Acuson, Mountain View, California, USA). The indications for fetal blood sampling were the investigation (karyotype and blood gas analysis) of severe intrauterine growth retardation in six, of hydrops in three, and of polyhydramnios in four, and the exclusion of coagulopathy in one twin after the intrauterine death of its monochorial sibling two to three weeks before. ${ }^{9} 1516$ Additional reasons for fetal blood sampling were in all cases to assess fetal wellbeing and to attempt to confirm the diagnosis by detecting differences in haemoglobin concentrations. All patients gave written informed consent. Fetal
Correspondence to: Dr Fisk.

Accepted 14 February 1990 
blood sampling was carried out with a 20 gauge needle inserted under ultrasound guidance. The site of sampling was the placental cord insertion in five, the intrahepatic vein in one, and a free loop of cord in three. Gross polyhydramnios precluded fetal blood sampling in the other fetus(es) in cases 3 and 6 .

The purity and fetal source of samples was checked at the time by separate red cell volume distributions on a particle size analyser (Coulter Channelyzer C-256, Coulter Electronics) and later confirmed by the Kleihauer test. ${ }^{17}$ The packed cell volume and haemoglobin concentration in fetal blood were determined by a Coulter $S$ Plus Counter. Nucleated red cells and reticulocyte counts were calculated from ratios obtained from blood films, which in turn were applied to results from the automated cell counter as described previously. ${ }^{18}$ Blood gas analysis was performed on $250 \mu$ l of fetal blood collected into heparinised capillary tubes. ${ }^{19}$ Published normal ranges were used for haemoglobin, ${ }^{20}$ packed cell volume, ${ }^{21}$ erythroblasts, ${ }^{22}$ and blood gases. ${ }^{23}$ Karyotypes were determined in fetal blood after short term fibroblast culture.

To document the presence of placental vascular anastomoses in vivo, adult blood (group $\mathrm{O}$ $\mathrm{Rh}$ negative and seronegative for cytomegalovirus was transfused into two donor fetuses. Fetal blood samples were then taken from their presumed recipient sibling to determine, using the Kleihauer technique, the passage of transfused adult red cells from one twin to the other.

The needle used for taking the sample of fetal blood was also used to provide access to the amniotic cavity. Four patients with gross polyhydramnios underwent therapeutic drainage of amniotic fluid to reduce amniotic pressure. ${ }^{24}{ }^{25}$ Amnioinfusion was carried out in one fetus to allow a thin septum to be seen; it had previously not been visible, but was suspected because of fetal immobility. ${ }^{14}$

Necropsy was performed by one of two perinatal pathologists in all but one case of fetal loss, in which consent was withheld. Postpartum evaluation of the configuration of placental membranes confirmed monochorionic diamniotic or triamniotic placentas in all. Meticulous injection studies were not performed, although shared areas on the chorionic surface were evaluated macroscopically. Pathological extramedullary haemopoiesis was defined as histological evidence of increased hepatic haemopoiesis out of proportion to that seen in normal fetuses of similar gestational age.

For reasons of clarity, sibling fetuses are denoted by the letters $A$ to $C$, with the recipient fetus in each pregnancy referred to as fetus $A$.

\section{Results}

Clinical details and outcome are shown in table 1. No immediate complications occurred as a result of the invasive procedures. Results of laboratory studies on fetal blood are shown in table 2. The karyotype in all in fetal blood was normal, and a normal karyotype was obtained from triplet fetuses $B$ and $C$ by culture of amniotic fluid cells obtained by amniocentesis. Each pregnancy was concordant for fetal sex. Clotting studies (platelets, thrombin time, fibrinogen, and fibrin degradation products) from the surviving fetus of case 2 were normal.

Six and $18 \mathrm{ml}$ of donor blood (packed cell volumes of 0.72 and 0.87 ) were transfused into the donor twins of cases 4 and 5, respectively. Kleihauer testing of fetal blood then obtained from the recipient twins 25 minutes (case 4) and 16 minutes (case 5) later showed that 145 and 70 cells $/ 1000$, respectively, had stained as adult cells. In both cases the needle tip was seen clearly within the umbilical vein of the recipient suggesting that appreciable maternal contamination was unlikely. This procedure was carried out in case 4 to document the sharing of circulations in utero, in view of the similar fetal haemoglobin concentrations. In contrast, this was done in case 5 at 36 weeks to improve the condition of the fetus before delivery by correcting polycythaemia and anaemia. In case 5 the recipient was sampled first, polycythaemia was confirmed, and $30 \mathrm{ml}$ of blood was with-

Table 1 Clinical details and outcome in six pregnancies complicated by fetofetal transfusion syndrome. Gestational age at time of blood sampling shown in parentheses

\begin{tabular}{|c|c|c|c|c|c|c|c|c|c|c|c|c|c|}
\hline & \multicolumn{2}{|c|}{ Case 1 (23 weeks) } & \multicolumn{2}{|c|}{ Case 2 (27 weeks) } & \multicolumn{2}{|c|}{ Case 3 (2I weeks) } & \multicolumn{2}{|c|}{ Case 4 (21 weeks) } & \multicolumn{2}{|c|}{ Case 5 (36 weeks) } & \multicolumn{3}{|c|}{ Case 6 (26 weeks) } \\
\hline & Fetus $A$ & Fetus B & Fetus $A$ & Fetus B & Fetus $A$ & Fetus B & Fetus $A$ & Fetus $B$ & Fetus $A$ & Fetus $B$ & Fetus $A$ & Fetus $B$ & Fetus $C$ \\
\hline $\begin{array}{l}\text { Volume of amniotic } \\
\text { fluid }\end{array}$ & Increased & Nil & Increased & Normal & Increased & Nil & Increased & Nil & Increased & Reduced & Increased & Normal & Reduced \\
\hline $\begin{array}{l}\text { Ultrasonic growth } \\
\text { (biparietal diameter } \\
\text { and abdominal } \\
\text { circumference) }\end{array}$ & Normal & $\leqslant$ Centile & $\begin{array}{l}\text { Intrauterine } \\
\text { death }\end{array}$ & $\leqslant$ Sth & Normal & $\begin{array}{l}<5 \text { th } \\
\text { Centile }\end{array}$ & Normal & $\begin{array}{l}<5 \text { th } \\
\text { Centile }\end{array}$ & Normal & $\begin{array}{l}<5 \text { th } \\
\text { Centile }\end{array}$ & Normal & Normal & $\begin{array}{l}<5 \text { th } \\
\text { Centile }\end{array}$ \\
\hline $\begin{array}{l}\text { End diastolic } \\
\text { frequencies detected } \\
\text { by umbilical } \\
\text { artery Doppler }\end{array}$ & $\begin{array}{l}\text { Not } \\
\text { measured }\end{array}$ & $\begin{array}{l}\text { Not } \\
\text { measured }\end{array}$ & $\begin{array}{l}\text { Intrauterine } \\
\text { death }\end{array}$ & $\begin{array}{l}\text { Not } \\
\text { measured }\end{array}$ & Present & Present & Present & Absent & Present & Present & Absent & Present & Absent \\
\hline $\begin{array}{l}\text { Hydrops present } \\
\text { Outcome }\end{array}$ & & No & & Yes & & No & No & \multirow[b]{2}{*}{$\begin{array}{l}\text { Intrauterine } \\
\text { death three } \\
\text { days later } \\
\text { our days later }\end{array}$} & & No & & & No \\
\hline Outcome & \multicolumn{2}{|c|}{$\begin{array}{l}\text { Miscarried one } \\
\text { day later }\end{array}$} & \multicolumn{2}{|c|}{$\begin{array}{l}\text { Preterm labour: } \\
\begin{array}{l}\text { Stillbirth } \\
\text { Neonatal } \\
\text { death }\end{array}\end{array}$} & \multicolumn{2}{|c|}{$\begin{array}{l}\text { Intrauterine deaths } \\
\text { six days later }\end{array}$} & - & & $\begin{array}{l}\text { Live birth } \\
\text { Elective ca } \\
\text { section n }\end{array}$ & $\begin{array}{l}\text { Live birth } \\
\text { esarean } \\
\text { ext day }\end{array}$ & $\begin{array}{l}\text { Preterm la } \\
\text { Stillbirth }\end{array}$ & $\begin{array}{l}\text { labour five da) } \\
\text { Neonatal } \\
\text { death } \\
\text { day } 8\end{array}$ & $\begin{array}{l}\text { ays later } \\
\text { Stillbirth }\end{array}$ \\
\hline Birth weight (g) & 560 & 420 & (444) & 730 & 355 & 200 & 480 & 400 & 2510 & 1658 & 1680 & 878 & 430 \\
\hline $\begin{array}{l}\text { Extramedullary } \\
\text { haemopoiesis } \\
\text { at necropsy }\end{array}$ & No & No & No & Yes & No necropsy & & Yes & No & Not applica & & Yes & No & Yes \\
\hline $\begin{array}{l}\text { Heart: body weight } \\
\text { ratio at necropsy }\end{array}$ & 0.015 & 0.005 & $(0.013)$ & 0.007 & No necropsy & & 0.012 & 0.003 & Not applica & & 0.006 & 0.007 & 0.005 \\
\hline
\end{tabular}


Table 2 Laboratory results on fetal blood. Case 2-fetus A, Case 3-fetus B, and Case 6-fetuses B and $C$ did not have samples taken. Results above the normal range are shown in bold type, those below in italics

\begin{tabular}{|c|c|c|c|c|c|c|c|c|c|}
\hline & \multicolumn{2}{|l|}{ Case 1} & \multirow{2}{*}{$\frac{\text { Case 2 }}{\text { Fetus B }}$} & \multirow{2}{*}{$\frac{\text { Case } 3}{\text { Fetus A }}$} & \multicolumn{2}{|l|}{ Case 4} & \multicolumn{2}{|l|}{ Case 5} & \multirow{2}{*}{$\frac{\text { Case } 6}{\text { Fetus A }}$} \\
\hline & Fetus $A$ & Fetus B & & & Fetus $A$ & Fetus B & Fetus $A$ & Fetus $B$ & \\
\hline $\begin{array}{l}\text { Haematology: } \\
\text { Packed celil volume } \\
\text { Haemoglobin }(g / /) \\
\text { Nucleated red cell count }\end{array}$ & $\begin{array}{l}0.53 \\
186\end{array}$ & $\begin{array}{l}0.47 \\
166\end{array}$ & $\begin{array}{l}0 \cdot 36 \\
128\end{array}$ & $\begin{array}{l}0.52 \\
180\end{array}$ & $\begin{array}{l}0.45 \\
110\end{array}$ & $\begin{array}{l}0.47 \\
153\end{array}$ & $\begin{array}{l}\mathbf{0 . 6 8} \\
230\end{array}$ & $\begin{array}{l}0.31 \\
99\end{array}$ & $\begin{array}{l}0.61 \\
185\end{array}$ \\
\hline $\begin{array}{l}\left(\times 10^{9} / 1\right) \\
\text { Reticulocytes }\left(\times 10^{9} / 1\right) \\
\text { As } \%\end{array}$ & $\begin{array}{l}52.9 \\
0.91 \\
16.5\end{array}$ & $\begin{array}{l}42.0 \\
0.51 \\
13.5\end{array}$ & $\begin{array}{l}7.3 \\
0.45 \\
19.0\end{array}$ & $\begin{array}{l}8.7 \\
0.48 \\
13.5\end{array}$ & $\begin{array}{l}1.9 \\
0.37 \\
11.0\end{array}$ & $\begin{array}{l}4 \cdot 8 \\
0 \cdot 67 \\
19 \cdot 7\end{array}$ & $\begin{array}{l}2.9 \\
0.46 \\
7.8\end{array}$ & $\begin{array}{l}17 \cdot 0 \\
0 \cdot 31 \\
12 \cdot 2\end{array}$ & $\begin{array}{l}27 \cdot 5 \\
0 \cdot 37 \\
8 \cdot 6\end{array}$ \\
\hline $\begin{array}{l}\text { Blood gases: } \\
\text { pH } \\
\mathrm{PCO}_{2}(\mathrm{kPa}) \\
\mathrm{PO}_{2}(\mathrm{kPa}) \\
\text { Base excess }\end{array}$ & $\begin{array}{l}7 \cdot 27 \\
6 \cdot 66 \\
1 \cdot 86 \\
-4 \cdot 5\end{array}$ & $\begin{array}{l}7 \cdot 30 \\
5.98 \\
2 \cdot 39 \\
-4 \cdot 3\end{array}$ & $\begin{array}{l}7 \cdot 38 \\
5 \cdot 11 \\
5 \cdot 10 \\
-1 \cdot 8\end{array}$ & $\begin{array}{l}7 \cdot 43 \\
4.68 \\
3.63 \\
0\end{array}$ & $\begin{array}{l}7 \cdot 37 \\
5.96 \\
3.02 \\
-0 \cdot 7\end{array}$ & $\begin{array}{l}7 \cdot 23 \\
8.81 \\
1 \cdot 52 \\
-2 \cdot 0\end{array}$ & $\begin{array}{l}7 \cdot 34 \\
5 \cdot 16 \\
4 \cdot 47 \\
-5 \cdot 2\end{array}$ & $\begin{array}{l}7 \cdot 39 \\
4 \cdot 93 \\
4 \cdot 08 \\
-4 \cdot 3\end{array}$ & $\begin{array}{l}7 \cdot 19 \\
7 \cdot 15 \\
1.41 \\
-8 \cdot 4\end{array}$ \\
\hline
\end{tabular}

Fetus $\mathrm{A}$, Case 4 , had samples taken after transfusion of the sibling fetus.

drawn to reduce the fetal packed cell volume. The donor was then sampled and transfused, its packed cell volume increasing from 0.31 to $0 \cdot 36$. The volume of red cells transfused was calculated as less than that removed from the recipient in case immediate fetofetal transfusion worsened the recipient's polycythaemia. The recipient was then resampled, a further $6 \mathrm{ml}$ of blood withdrawn, and $15 \mathrm{ml}$ normal saline instilled intravascularly. Dilutional exchange transfusion in utero was abandoned at this stage because of a transient bradycardia. Umbilical artery flow velocity waveforms remained normal throughout. At elective delivery the next day, Kleihauer testing of the recipient's cord blood showed that 160/1000 cells were adult. The donor's neonatal course was uncomplicated, but the recipient required dilutional exchange transfusion after the packed cell volume peaked at 0.72 ; the infant subsequently developed necrotising enterocolitis, and recovered with conservative management.

There were 11 fetal or perinatal losses, giving a total perinatally related wastage of $85 \%$.

The diagnostic criteria by which all these pregnancies were considered to have been complicated by fetofetal transfusion syndrome are shown in table 3. Discordant growth and amniotic fluid volumes in the presence of monochorionic placentas was seen on ultrasonography in all, and hydrops was noted in three recipient fetuses. After delivery, fetofetal transfusion syndrome was confirmed in each by differences in fetal weight of $20 \%$ or more. In the four that underwent necropsy, extramedullary haemopoiesis in the donor, with or without relative macrocardia in the recipient, provided additional confirmation of the diagnosis. ${ }^{26}$ In the remaining two, additional confirmation was achieved by the difference in haemoglobin concentrations (case 5), and the clinical appearance at delivery (case 3$)^{3}$

\section{Discussion}

Fetal haematology in these pregnancies with fetofetal transfusion syndrome suggests that, unlike postnatally, a haemoglobin difference of $50 \mathrm{~g} / \mathrm{l}$ or more is not necessarily found in utero. In this series, only one of three twin pregnancies in which both fetuses were sampled showed major differences in haemoglobin values (case 5 ), and this was in a pregnancy with a chronic well compensated fetofetal transfusion syndrome sampled late in the third trimester. In contrast, the remaining two without major differences in haemoglobin concentrations were at much earlier gestations ( 21 and 23 weeks). Case 1 showed a degree of polycythaemia in both fetuses, while in case 4 , polycythaemia was found in the donor and not in the recipient. In this atypical case, however, a marginal velamentous cord insertion with abnormal umbilical Doppler flow implicated deficient placentation in the donor's intrauterine growth retardation, itself a known cause for polycythaemia. In the two multiple pregnancies in which only the recipient was sampled, raised haemoglobin concentrations and packed cell volumes were consistent with the diagnosis of fetofetal transfusion syndrome. Because of the above discrepancies, and the existence of other mechanisms for polycythaemia, however, isolated polycythaemia in one twin or triplet cannot be considered diagnostic.

Rausen et al were the first to suggest that a

Table 3 Presence of diagnostic features in six pregnancies complicated by fetofetal transfusion syndrome

\begin{tabular}{|c|c|c|c|c|c|c|c|c|c|}
\hline \multirow{2}{*}{$\begin{array}{l}\text { Case } \\
\text { No }\end{array}$} & \multirow{2}{*}{$\begin{array}{l}\text { Ultrasound measurements } \\
\text { of biparietal diameter } \\
\text { and abdominal } \\
\text { circumference } e^{40} \leqslant 5 \text { th } \\
\text { centile in one fetus } \\
\text { and not the other(s) } \\
\text { (discordant growth) }\end{array}$} & \multirow{2}{*}{$\begin{array}{l}\text { Polyhydramnios } \\
\text { in one sac and } \\
\text { not the other(s) } \\
\text { (discordant } \\
\text { volume) }\end{array}$} & \multirow{2}{*}{$\begin{array}{l}\text { Hydrops in } \\
\text { recipient }\end{array}$} & \multirow{2}{*}{$\begin{array}{l}\text { Difference in } \\
\text { haemoglobin } \\
\text { concentration } \\
\text { of } \geqslant 50 \mathrm{~g} / \mathrm{l} \\
\text { between } \\
\text { fetuses }\end{array}$} & \multicolumn{2}{|c|}{ Signs of shared circulation* } & \multirow{2}{*}{$\begin{array}{l}\text { Difference in } \\
\text { birth weight of } \\
\geqslant 20 \% \text { between } \\
\text { fetuses }\end{array}$} & \multirow{2}{*}{$\begin{array}{l}\text { Extramedullary } \\
\text { haemopoiesis } \\
\text { in donor }\end{array}$} & \multirow{2}{*}{$\begin{array}{l}\text { Difference in } \\
\text { heart: body weight } \\
\text { ratio of } \geqslant 50 \% \\
\text { between fetuses } \\
\text { at necropsy }\end{array}$} \\
\hline & & & & & In vivo & In vitro & & & \\
\hline $\begin{array}{l}1 \\
2 \\
3 \\
4\end{array}$ & $\begin{array}{l}\text { Yes } \\
\text { Yes } \\
\text { Yes } \\
\text { Yes } \\
\text { Yes } \\
\text { Yes }\end{array}$ & $\begin{array}{l}\text { Yes } \\
\text { Yes } \\
\text { Yes } \\
\text { Yes } \\
\text { Yes } \\
\text { Yes }\end{array}$ & $\begin{array}{l}\text { No } \\
\text { Yes } \\
\text { No } \\
\text { No } \\
\text { Yes } \\
\text { Yes }\end{array}$ & $\begin{array}{l}\text { No } \\
\text { Not applicable } \\
\text { Not applicable } \\
\text { No } \\
\text { Yes } \\
\text { Not applicable }\end{array}$ & $\begin{array}{l}\text { Not applicable } \\
\text { Not applicable } \\
\text { Not applicable } \\
\text { Yes } \\
\text { Yes } \\
\text { Not applicable }\end{array}$ & $\begin{array}{l}\text { Yes } \\
\text { No } \\
\text { Not applicable } \\
\text { Yes } \\
\text { No } \\
\text { No }\end{array}$ & $\begin{array}{l}\text { Yes } \\
\text { Not applicablet } \\
\text { Yes } \\
\text { Yes } \\
\text { Yes } \\
\text { Yes }\end{array}$ & $\begin{array}{l}\text { No } \\
\text { Yes } \\
\text { Not applicable } \\
\text { No } \\
\text { Not applicable } \\
\text { Yes }\end{array}$ & $\begin{array}{l}\text { Yes } \\
\text { Yes } \\
\text { Not applicable } \\
\text { Yes } \\
\text { Not applicable } \\
\text { No }\end{array}$ \\
\hline
\end{tabular}

* Signs of shared circulation in vivo means that adult red cells were detected in the recipient after adult blood had been transfused into the donor, whereas in vitro shared

circulation refers to the presence of placental superficial anastomoses.
+ Retrospective calculation using centile charts of the estimated fetal weight of the surviving twin suggested a difference of $\geqslant 20 \%$ at that time. 
difference of $50 \mathrm{~g} / 1$ in neonatal haemoglobin concentrations was diagnostic of fetofetal transfusion syndrome. ${ }^{4}$ In their series, 19 of 130 monochorionic twins had such a difference, while no set of dichorionic twins had a discrepancy of greater than $33 \mathrm{~g} / 1$. This criterion for the diagnosis of fetofetal transfusion syndrome has since been widely adopted. ${ }^{5-7}$ Haemoglobin discordance has, however, also been reported in dichorionic twins. ${ }^{5}$ A recent study reported that seven of 13 sets of twins with neonatal haemoglobin discordance of more than $50 \mathrm{~g} / \mathrm{l}$ were in fact dichorionic. ${ }^{27}$ Fetofetal transfusion syndrome occurs almost exclusively in monochorionic placentas, although rarely vascular communications have been reported in fused dichorionic placentas. ${ }^{2}$ On the other hand, intrauterine growth retardation is common in dichorionic twins, so that haemoglobin discordance in dichorionic twins is far more likely to reflect polycythaemia secondary to intrauterine growth retardation. Tan et al described 35 sets of twins with the required haemoglobin difference, but made no mention of placental chorionicity. ${ }^{6}$ In nine of their pregnancies the polycythaemic twin was smaller than the anaemic twin, suggesting that several cases of dichorionic twins with intrauterine growth retardation were falsely diagnosed as having fetofetal transfusion syndrome. Although the standard neonatal criteria have recently been questioned, ${ }^{27}$ it seems reasonable to apply them at birth provided that they are applied only to monochorionic twins in which the heavier twin has the higher haemoglobin concentration.

This discrepancy between the classic postnatal findings and our observations made in utero may be related to differences in gestation or the duration and degree of shunting, or both. Presentation in the midtrimester suggests a more acute form of fetofetal transfusion syndrome in which there may have been insufficient time for haematological compensation. Alternatively, the considerable mixing of the circulations implicit in large shunts may not necessarily be reflected in differences in haemoglobin concentrations.

Evidence of erythroblastosis (increased nucleated red cells and reticulocytes) was found in all the fetuses sampled, usually to a greater extent in the donor. Erythroblastaemia in the recipient could result either from fetofetal transfusion of donor erythroblasts, ${ }^{28}$ or from the action of donor erythropoietin on the recipient marrow. ${ }^{29}$ This latter suggestion would explain our finding of extramedullary haemopoiesis in some recipients. In addition, erythroblastaemia in the recipient may be secondary to hypoxia, which we found in four of five of the recipients sampled.

An alternative approach to diagnosis is in vivo demonstration of appreciable sharing of circulations. This was achieved in two pregnancies by giving a readily detectable safe marker with subsequent demonstration of its passage in substantial quantities into the recipient. The finding of a considerable proportion of adult red cells in the recipients $(14.5$ and $7 \%$ of red cells in cases 4 and 5 , respectively) after only short intervals suggests that a large amount of transfer occurred rapidly. We found no such transfer in an $\mathrm{Rh}$ alloimmunised monochorionic twin pregnancy uncomplicated by fetofetal transfusion syndrome in whom intrauterine transfusion was indicated for fetal anaemia, but this is anecdotal evidence and the technique warrants further evaluation in the diagnosis of fetofetal transfusion syndrome in utero.

Fetal blood sampling in this series supplied additional information about fetal wellbeing. Four of nine fetuses were acidaemic, while two others in addition to these four were also hypoxaemic. As with other high risk pregnancies, fetal acid base balance may contribute to the assessment of fetal compromise and to the timing of intervention or delivery, or both.

This series confirms the extremely high mortality $(85 \%)$ in fetofetal transfusion syndrome, ${ }^{13} 30$ and reflects both the severity of disease and the early gestation of the patients referred. All fetal losses in this series occurred before 28 weeks, and survival after diagnosis of fetofetal transfusion syndrome in the second trimester is most unusual. A $100 \%$ perinatal mortality rate has been reported in a series of eight monochorial pregnancies complicated by polyhydramnios in the midtrimester. ${ }^{30}$ Thus our finding of fetal hypoxaemia or acidaemia, or both, in four of five pregnancies that ended in fetal loss is hardly surprising. It seems unlikely that the losses in our series were related to the invasive procedures; most complications of fetal blood sampling occur immediately, and none were observed here.

In view of the uniformly poor outcome of fetofetal transfusion syndrome in the second trimester, aggressive therapeutic measures may be warranted. Laser ablation of superficial placental anastomoses has been investigated in animal studies ${ }^{31}$; it is, however, the deeper and not the more accessible superficial anastomoses that seem to be responsible for the haemodynamic imbalance in fetofetal transfusion syndrome. ${ }^{928}$ Selective fetocide of one twin has been reported in three pregnancies with fetofetal transfusion syndrome, two of which resulted in live singletons born at full term. ${ }^{32-34}$ In no case was there evidence of hydrops or other fetal compromise, this drastic procedure being carried out primarily to allow prolongation of pregnancies threatened by gross polyhydramnios. In such cases simpler treatments deserve consideration. Serial amniocentesis has been recommended to allow symptomatic relief and to delay preterm labour, ${ }^{35}$ although some have found it unsuccessful. ${ }^{33}$ We have recently shown that removal of small quantities of amniotic fluid in gross polyhydramnios restores raised amniotic fluid pressure to normal. ${ }^{25}$ Although this procedure seems to alleviate maternal symptoms, it is not known how long thereafter it takes for amniotic pressure to rise again. Treating the mother with indomethacin has also been suggested to alleviate polyhydramnios, ${ }^{36}$ as it reduces fetal urine output. ${ }^{37}$ This approach is contraindicated in the presence of oligohydramnios in one twin, ${ }^{36}$ however, a feature in five of the six pregnancies reported here.

An alternative to selective fetocide is sug- 
gested by the report of Vetter and Schneider ${ }^{38}$ who noted resolution of fetofetal transfusion syndrome in two pregnancies after iatrogenic puncture of a chorionic plate vessel at amniocentesis with consequent intra-amniotic haemorrhage. Repeated phlebotomy of the recipient and transfusion of the donor has been considered as a treatment for fetofetal transfusion syndrome. ${ }^{33}$ The degree of shunting that we found in vivo in cases 4 and 5 was substantial, however, indicating that serial 'give and take' transfusion would be unlikely to be of long term benefit. Given that the hydropic recipient twin seems relatively more at risk than its donor, venepuncture of the recipient alone warrants consideration as a treatment for fetofetal transfusion syndrome.

NMF was the recipient of a Gladys Dodds Fellowship from the Royal College of Obstetricians and Gynaecologists and a Foreman Fellowship from Royal Prince Alfred Hospital, Sydney, Australia. AB was supported by a CIRIT Fellowship, Generalitat de Catalunya, and the Prenatal Diagnosis Unit, University of Barcelona. CH holds a Royal Society and a Council of Europe Award. YT acknowledges the Anandamahidol Foundation and Chulalongkorn University, Thailand.

1 Galea P, Scott JM, Goel KM. Feto-fetal transfusion syndrome. Arch Dis Child 1982;57:781-3.

2 Robertson EG, Neer KJ. Placental injection studies in twin gestation. Am $\mathcal{F}$ Obstet Gynecol 1983;147:170-4

3 Naeye RL. Human intrauterine parabiotic syndrome and its complications. N Engl f Med 1963;268:804-9.

4 Rausen AR, Seki M, Strauss L. Twin transfusion syndrome. $\mathcal{f}$ Pediatr 1965;66:613-28.

5 Abraham JM. Intrauterine feto-fetal transfusion syndrome: clinical observations and speculations on pathogenesis. Clin Pediatr 1967;6:405-10.

6 Tan KL, Tan R, Tan SH. The twin transfusion syndrome. Clin Pediatr 1979;18:111-4.

7 Klebe JC, Ingomar CJ. The fetofetal circulation during parturition illustrated by the interfetal transfusion syndrome. Pediatrics 1972;49:112-6.

8 Brown DG, Benson CB, Driscoll SG, Doubilet PM. Twintwin transfusion syndrome: sonographic findings. Radio twin transfusion syind

9 Benirschke K, Kim CK. Multiple pregnancy. N Engl f Med 1973;288:1276-84.

10 Babbington MV, Wittmann BK. Fetal transfusion syndrome: antenatal factors predicting outcome. Am F Obstet Gymecol 1989;160:913-5.

11 Brennan JN, Diwan RJ, Rosen MG, Bellon EM. Fetofetal transfusion syndrome: prenatal ultrasonographic diagnosis. Radiology 1982;143:535-6.

12 Macafee CAJ, Fortune DW, Beischer NA. Non-immunological hydrops fetalis. Fournal of Obstetrics and Gynaecology of the British Commonwealth 1970;77:226-37.

13 Pretorius DH, Manchester D, Barkin S, Parker S, Nelson TR. Doppler ultrasound of twin twin transfusion syndrome. F Ultrasound Med 1988;7:117-24.

14 Mahony BS, Filly RA, Callen PW. Amnionicity and chorionicity in twin pregnancies: prediction using ultrasound. Radiology 1985;155:205-9.

15 Moore CM, McAdams AJ, Sutherland J. Intrauterine disseminated intravascular coagulation: a syndrome of
multiple pregnancy with a dead twin fetus. Pediatrics 1969; multiple preg
16 Cox WL, Forestier F, Capella-Pavlovsky M, Daffos F. Fetal blood sampling in twin pregnancies. Fetal Therapy 1987;2: 101-8.

17 Mibashan RS, Rodeck CH, Thompson JK. Prenatal diagnosis of the haemophilias. In: Bloom $\mathrm{AL}$, ed. The haemophilias. Edinburgh: Churchill Livingstone, 1982: 176-96.

18 Fisk NM, Tannirandorn Y, Santolaya J, Nicolini U, Letsky EA, Rodeck CH. Fetal macrocytosis in association with chromosomal abnormalities. Obstet Gynecol 1989;74:611-6.

19 Nicolini U, Santolaya J, Fisk NM, et al. Changes in fetal acid base status during intravascular transfusion. Arch Dis Child 1988;63:710-4.

20 Nicolaides KH, Clewell WH, Mibashan RS, Soothill PW, Rodeck CH, Campbell S. Fetal haemoglobin measurement in the assessment of red cell isoimmunisation. Lancet 1988; i: 1073-5.

21 Cox WL, Daffos F, Forestier F, et al. Physiology and management of intrauterine growth retardation: a biologic approach with fetal blood sampling. Am $\mathcal{F}$ Obstet Gynecol 1988;159:36-41.

22 Millar DS, Davis LR, Rodeck $\mathbf{C H}$, Nicolaides $\mathbf{K H}$ Mibashan RS. Normal blood cell values in the early midMibashan RS. Normal blood cell values in the

23 Soothill PW, Nicolaides KH, Rodeck CH, Campbell S. Effect of gestational age on fetal and intervillous blood gases and acid-base value

24 Nicolini U, Fisk NM, Talbert DG, et al. Intrauterine manometry: technique and application to fetal pathology. Prenat Diagn 1989;9:243-54

25 Fisk NM, Tannirandorn Y, Nicolini U, Talbert DG, Rodeck CH. Amniotic pressure in disorders of amniotic fluid volume. Obstet Gynecol (in press).

26 Naeye RL. The fetal and neonatal development of twins. Pediatrics 1964:33:546-53.

27 Danskin FH, Neilson JP. Twin-to-twin transfusion syndrome: what are the appropriate diagnostic criteria? $A m \mathcal{J}$ Obstet Gymecol 1989;161:365-9.

28 Aherne W, Strong IS, Corney G. The structure of the placenta in the twin transfusion syndrome. Biol Neonat placenta in the

29 Dudley DKL, D'Alton ME. Single fetal death in twin gestation. Semin Perinatol 1986;10:65-72.

30 Weir PE, Ratten GJ, Beischer NA. Acute polyhydramnios a complication of monozygous twin pregnancy. Br $\mathcal{O}$ Obstet Gymacol 1979;86:849-53.

31 DeLia JE, Gukierski MA, Lundergan DK, Kochenour NK. Neodymium: yttrium-aluminum-garnet laser occulsion of rhesus placental vasculature via fetoscopy. Am $\mathcal{f}$ Obstet Gynecol 1989;160:485-9.

32 Wittmann BK, Farquharson DF, Thomas WDS, Baldwin VJ, Wadsworth $L$. The role of feticide in the managemen of severe twin transfusion syndrome. Am $\mathcal{F}$ Obstet Gynecol 1986;155:1023-6.

33 Weiner CP. Diagnosis and treatment of twin to twin transfusion in the mid-second trimester of pregnancy. Fetal Therapy 1987;2:71-4.

34 Chescher NC, Seeds JW. Polyhydramnios and oligohydramnios in twin gestations. Obstet Gynecol 1988;71: hydram.

35 Feingold M, Cetrulo CL, Newton ER, Weiss J, Shakr C, Shmoys S. Serial amniocenteses in the treatment of twin to Shmoys S. Serial amniocenteses in the treatment of twin to twin transfusion complicated with acute

36 Lange IR, Harman CR, Ash KM, Manning FA, Menticoglou S. Twins with hydramnios: treating premature labor at source. Am $\mathcal{f}$ Obstet Gyncol 1989;160: 552-7.

37 Kirshon B, Moise KJ, Wasserstrum N, Ou C-N, Huhta JC. Influence of short-term indomethacin therapy on fetal urine output. Obstet Gynecol 1988;72:51-3.

38 Vetter K, Schneider KTM. Iatrogenous remission of twin transfusion syndrome. Am $\mathcal{f}$ Obstet Gynecol 1988;158: 221.

39 Campbell S, Newman GB. Growth of fetal biparietal diameter during normal pregnancy. Br $\mathcal{F}$ Obstet Gymaecol 1971;78: 513-9.

40 Campbell S, Wilkin D. Ultrasonic assessment of fetal abdominal circumference in the estimation of fetal weight. Br F Obstet Gynaecol 1975;82:689-91. 